\title{
Chromium propionate supplementation during the peripartum period interacts with starch source fed postpartum: Production responses during the immediate postpartum and carryover periods
}

\author{
R. J. Rockwell and M. S. Allen ${ }^{1}$ \\ Department of Animal Science, Michigan State University, East Lansing 48824
}

\begin{abstract}
Forty-eight multiparous cows were used in a randomized complete block design experiment with a 2 $\times 2$ factorial arrangement of treatments to determine the interaction between chromium propionate $(\mathrm{CrPr})$ supplementation and sources of corn varying in ruminal starch fermentability on production responses during the postpartum (PP) and carryover periods. During the peripartum period (28 d before expected parturition until $28 \mathrm{~d}$ PP), diets were top-dressed $(20 \mathrm{~g} / \mathrm{d})$ with either CrPr (KemTRACE Chromium Propionate, Kemin Industries, Des Moines, IA; $8 \mathrm{mg}$ of $\mathrm{Cr} /$ cow per day) or control (Con; ground corn). At parturition, cows were randomly assigned to corn treatment within $\mathrm{CrPr}$ and Con treatments: dry corn (DC) or high-moisture corn (HMC). Treatment combinations ( $\mathrm{CrPr} / \mathrm{DC}, \mathrm{CrPr} /$ HMC, Con/DC, and Con/HMC) were fed from parturition until 28 d PP (treatment period). Cows were fed a common diet to evaluate potential carryover effects of the treatment diets from 29 to $84 \mathrm{~d}$ PP (carryover period). The $\mathrm{CrPr}$ and corn treatments interacted over time to affect yield of $3.5 \%$ fat-corrected milk (FCM) during both the treatment and carryover periods. The $\mathrm{CrPr} / \mathrm{HMC}$ treatment combination tended to increase FCM compared with Con/DC and Con/HMC by 28 d PP (57.4 vs. 48.6 and $48.5 \mathrm{~kg} / \mathrm{d}$, respectively) and increased FCM compared with Con/DC by $42 \mathrm{~d}$ PP $(59.2$ vs. $44.8 \mathrm{~kg} / \mathrm{d})$. The $\mathrm{CrPr}$ tended to increase milk yield ( 55.4 vs. $51.9 \mathrm{~kg} / \mathrm{d}$ ) regardless of corn source during the carryover period after treatment ceased. Daily and cumulative DMI were not affected by treatment during the PP period, but $\mathrm{CrPr}$ and corn treatments interacted over time to affect daily DMI during the carryover period; DMI was generally higher for $\mathrm{CrPr} /$ $\mathrm{HMC}$, lower for Con/DC, and intermediate for $\mathrm{CrPr} /$ DC and Con/HMC from 29 to 84 d PP. Supplementation of CrPr throughout the peripartum period interacted with starch source in PP diets over time to
\end{abstract}

Received September 2, 2015.

Accepted November 30, 2015.

${ }^{1}$ Corresponding author: allenm@msu.edu affect production responses that were sustained after treatment application ceased.

Key words: chromium propionate, starch fermentability, transition period, early lactation

\section{INTRODUCTION}

Chromium (Cr) has been reported to increase insulin sensitivity of tissues in cattle (Subiyatno et al., 1996; Hayirli et al., 2001; Sumner et al., 2007) and other species (Matthews et al., 2001; Clodfelder et al., 2005; Wang and Cefalu, 2010). A decrease in insulin sensitivity, which could lead to increased fat mobilization, has been described in dairy cattle around parturition (Bell, 1995). Excessive net lipolysis in the peripartum period can result in hepatic steatosis, ketosis, and reduced feed intake (Allen and Piantoni, 2013). The reduction in feed intake during the peripartum period might be caused by a satiety signal from hepatic oxidation of the consistent supply of fatty acids to the liver (Allen et al., 2005). Strategies that increase insulin sensitivity, such as Cr supplementation, might decrease lipolysis through the transition from pregnancy to lactation, benefiting feed intake and milk yield (Hayirli et al., 2001; McNamara and Valdez, 2005). Although Cr supplementation increased milk yield in those and other experiments (Smith et al., 2005; Sadri et al., 2009; Soltan, 2010), effects on productive performance have been inconsistent; Cr supplementation did not affect milk yield (Yang et al., 1996; Yasui et al., 2014) or feed intake (Yang et al., 1996; Sadri et al., 2009; Soltan, 2010; Yasui et al., 2014) during this period in other experiments.

Inconsistent effects on feed intake and milk production might be partially related to variation in starch fermentability of rations among studies. Fermentability of starch sources fed to dairy cattle is highly variable and affects both feed intake of lactating cows (Allen, 2000 ) and insulin response to a glucose challenge (Bradford and Allen, 2007). Propionate production by rumen microbes increases with increasing ruminal starch fermentability (Hobson, 1972). Because propionate is hypophagic (Forbes, 2007) and its hypophagic effects 
are elevated when cows are in a lipolytic state (Allen, 2014), a reduction in lipolysis in the peripartum period might especially benefit cows offered rations containing highly fermentable starch. We hypothesized that production response to $\mathrm{Cr}$ propionate supplementation through the peripartum period will be dependent upon starch source varying in ruminal fermentability fed during the postpartum (PP). Our objective was to determine if diets containing corn grain sources varying in ruminal starch fermentability affect production responses to chromium propionate supplementation differently in the PP period.

\section{MATERIALS AND METHODS}

\section{Animal Housing and Care}

All experimental procedures were approved by The Institutional Animal Care and Use Committee at Michigan State University (East Lansing). The experiment began on December 9, 2009, and finished on October 7, 2010. Cows were housed in individual tiestalls for the duration of the experiment. Cows were fed once daily $(1000 \mathrm{~h})$ at $110 \%$ of expected intake throughout the entire experiment. After parturition, cows were milked twice daily at 0400 and $1400 \mathrm{~h}$. Standard reproduction and herd health checks and breeding practices were maintained throughout this study.

\section{Design and Treatments}

Forty-eight multiparous Holstein cows at the Michigan State University Dairy Cattle Teaching and Research Center were used in a randomized complete block design with a $2 \times 2$ factorial arrangement of treatments with 12 cows per treatment. Cows were blocked by date of parturition (within $90 \mathrm{~d}$ ), BCS (up to 1 unit difference using a 5 -point scale, where $1=$ thin and $5=$ fat; Wildman et al., 1982), and previous lactation 305-d mature-equivalent milk production (within $5,500 \mathrm{~kg}$ ). At $28 \pm 3$ d prepartum, cows within a block were randomly assigned to $\mathrm{Cr}$ treatment based upon expected parturition date. During the peripartum period $(28 \pm 3$ $\mathrm{d}$ before expected parturition until $28 \pm 3 \mathrm{~d} \mathrm{PP}$ ) half of the cows $(\mathrm{n}=24)$ were top-dressed daily $(20 \mathrm{~g} / \mathrm{d})$ with chromium propionate $\mathbf{C r P r}$; KemTRACE Chromium Propionate, Kemin Industries, Des Moines, IA; $8 \mathrm{mg}$ of $\mathrm{Cr} /$ cow per day) and the other half $(\mathrm{n}=24)$ with control (Con; ground corn). At parturition, cows were randomly assigned to corn treatment within $\mathrm{CrPr}$ and Con treatments, dry corn (DC) or high-moisture corn (HMC) in the base diet, which resulted in 12 cows per treatment combination. Treatment combinations (CrPr/DC, $\mathrm{CrPr} / \mathrm{HMC}, \mathrm{Con} / \mathrm{DC}$, and Con/HMC) were fed from parturition until $28 \pm 3 \mathrm{~d}$ PP (treatment period). All cows were fed a common diet to evaluate possible carryover effects of the treatment diets from 29 to $84 \pm 3 \mathrm{~d}$ PP (carryover period). Cows were offered a prepartum diet beginning $28 \pm 3 \mathrm{~d}$ before expected parturition date. Cows switched diets on the same day each week, except that the corn treatment diets began on the day of parturition or the next feeding, depending on time of day of parturition. Treatment diets were mixed daily in a tumble mixer and common diets (prepartum and carryover) were mixed daily in a mixer wagon. All diets were formulated to meet or exceed predicted requirements for protein, minerals, and vitamins according to NRC (2001), and water was available at all times in each stall. To adjust for concentrations of individual ingredients in the different TMR, forages were sampled weekly and composited and analyzed every $2 \mathrm{wk}$, whereas concentrates were sampled weekly and composited and analyzed every month. Dry matter of fermented feeds was determined twice per week by a Koster moisture tester (Koster Moisture Tester Inc., Brunswick, $\mathrm{OH}$ ) and diets were adjusted accordingly. Ingredient and nutrient composition of the 4 diets fed throughout the experiment are listed in Table 1.

\section{Data and Sample Collection}

All samples and body measurements were collected or recorded on the same day of the week during the entire experiment so all collection days are $\pm 3 \mathrm{~d}$ relative to the first day on the treatment rations. Feed offered and refused were recorded for each cow daily throughout the entire experiment. Samples of all diet ingredients $(0.5 \mathrm{~kg})$ and orts from each cow $(\sim 12.5 \%)$ were collected weekly during the entire experiment and stored in plastic bags at $-20^{\circ} \mathrm{C}$ until processed. Milk yield was recorded at each milking from parturition until $84 \mathrm{~d}$ PP. Milk samples were collected weekly at each milking, from calving until $28 \mathrm{~d}$ PP, and then every other week until $84 \mathrm{~d}$ PP. Milk samples were stored with preservative (bronopol tablet; D\&F Control Systems, San Ramon, CA) at $4^{\circ} \mathrm{C}$ for component analysis (Universal Lab Services, East Lansing, MI). Body condition score was recorded $35 \mathrm{~d}$ before expected date of parturition to block cows. Body weight and BCS were recorded every other week from $28 \mathrm{~d}$ prepartum to $28 \mathrm{~d} \mathrm{PP}$, and every 4 wk during the carryover period. Body condition was scored on a 5 -point scale by 3 trained investigators (Wildman et al., 1982).

\section{Sample Analysis}

Milk samples were analyzed for fat, true protein, lactose, MUN, and SCC by infrared spectroscopy (AOAC 
Table 1. Ingredient and nutrient composition of prepartum, postpartum, and carryover diets

\begin{tabular}{|c|c|c|c|c|}
\hline \multirow[b]{2}{*}{ Item } & \multirow{2}{*}{$\begin{array}{l}\text { Prepartum } \\
\text { period }\end{array}$} & \multicolumn{2}{|c|}{ Postpartum period } & \multirow{2}{*}{$\begin{array}{l}\text { Carryover } \\
\text { period }\end{array}$} \\
\hline & & DC & HMC & \\
\hline \multicolumn{5}{|l|}{ Ingredient, $\%$ of DM } \\
\hline Dry ground corn $(\mathrm{DC})^{1,2,3}$ & - & 23.3 & - & 7.1 \\
\hline High-moisture corn $(\mathrm{HMC})^{1,2,3}$ & - & - & 23.3 & 6.6 \\
\hline Corn silage & 43.6 & 25.0 & 25.0 & 32.3 \\
\hline Alfalfa silage & - & 19.2 & 19.2 & 8.9 \\
\hline Grass hay & 24.3 & - & - & 5.2 \\
\hline Alfalfa hay & - & 11.8 & 11.8 & 2.0 \\
\hline Whole cottonseeds & - & - & - & 5.9 \\
\hline Soyhulls & - & - & - & 8.9 \\
\hline Soybean meal & 17.5 & 12.9 & 12.9 & 14.6 \\
\hline SoyChlor & 1.8 & - & - & - \\
\hline Vitamin-mineral mix & $12.8^{4}$ & $7.8^{5}$ & $7.8^{5}$ & $8.1^{6}$ \\
\hline \multicolumn{5}{|l|}{ Nutrient composition } \\
\hline DM, $\%$ & 49.2 & 50.3 & 48.0 & 53.2 \\
\hline $\mathrm{OM}, \%$ of $\mathrm{DM}$ & 92.6 & 92.6 & 92.6 & 93.2 \\
\hline Starch, \% of DM & 14.2 & 26.4 & 26.5 & 27.9 \\
\hline NDF, $\%$ of DM & 38.5 & 31.4 & 31.1 & 32.4 \\
\hline NDF from forage, $\%$ & 90.7 & 87.1 & 88.6 & 63.1 \\
\hline $\mathrm{CP}, \%$ of $\mathrm{DM}$ & 15.7 & 16.2 & 16.2 & 16.6 \\
\hline Ether extract, $\%$ of DM & 3.0 & 3.9 & 3.8 & 4.32 \\
\hline Chromium, mg/kg of DM & 1.44 & 0.68 & 0.67 & 0.37 \\
\hline \multirow{2}{*}{\multicolumn{5}{|c|}{$\begin{array}{l}{ }^{1} \text { Mean particle size }(\mu \mathrm{m}): \text { dry sieve }(\mathrm{DC}=1,397 ; \mathrm{HMC}=3,758) \text {; wet sieve }(\mathrm{DC}=1,450 ; \mathrm{HMC}=3,945) \text {. } \\
{ }^{2} \text { In vitro starch digestibility }(7 \mathrm{~h}): 29 \% \text { for } \mathrm{DC} \text { and } 67 \% \text { for } \mathrm{HMC} \text {. } \\
{ }^{3} \text { Dry matter }=86.8 \% \text { for } \mathrm{DC} \text { and } 66.2 \% \text { for } \mathrm{HMC} \text {. }\end{array}$}} \\
\hline & & & & \\
\hline \multicolumn{5}{|c|}{$\begin{array}{l}{ }^{4} \text { Prepartum mineral and vitamin mix included } 36.2 \% \text { SoyChlor (West Central Cooperative, Ralston, IA), } \\
35.9 \% \text { dry ground shelled corn, } 8.2 \% \text { limestone, } 6.6 \% \text { ReaShure choline (Balchem Inc., New Hampton, NY), } \\
5.3 \% \text { dicalcium phosphate, } 2.7 \% \text { magnesium sulfate, } 1.1 \% \text { trace mineral, and vitamin A, D, and E premix. }\end{array}$} \\
\hline \multicolumn{5}{|c|}{$\begin{array}{l}{ }^{5} \text { Postpartum mineral and vitamin mix included } 24.4 \% \text { dry ground shelled corn, } 21.3 \% \text { molasses, } 10.9 \% \text { lime- } \\
\text { stone, } 9.4 \% \text { blood meal, } 8.8 \% \text { sodium bicarbonate, } 6.6 \% \text { dicalcium phosphate, } 4.1 \% \text { ReaShure choline, } 3.1 \% \\
\text { magnesium sulfate, } 2.8 \% \text { white salt, } 1.9 \% \text { animal fat, } 2.6 \% \text { trace mineral mix, and vitamin A, D, and E premix. }\end{array}$} \\
\hline \multicolumn{5}{|c|}{$\begin{array}{l}{ }^{6} \text { Carryover period mineral and vitamin mix included } 57.4 \% \text { dry ground shelled corn, } 12.2 \% \text { limestone, } 6.9 \% \\
\text { dicalcium phosphate, } 3.4 \% \text { animal fat, } 3.1 \% \text { magnesium sulfate, } 2.8 \% \text { white salt, } 1.7 \% \text { trace mineral mix, and } \\
\text { vitamin A, D, and E premix. }\end{array}$} \\
\hline
\end{tabular}

International, 1997), by the Michigan Herd Improvement Association (Universal Lab Services). Component corrected milk yields were calculated using the following formulas:

$$
\begin{gathered}
3.5 \% \text { FCM }(\mathrm{kg} / \mathrm{d})=0.4324 \times \text { milk }(\mathrm{kg} / \mathrm{d}) \\
+16.216 \times \text { fat }(\mathrm{kg} / \mathrm{d}), \text { and } \\
\operatorname{ECM}(\mathrm{kg} / \mathrm{d})=0.327 \times \text { milk }(\mathrm{kg} / \mathrm{d}) \\
+12.95 \text { fat }(\mathrm{kg} / \mathrm{d})+7.65 \times \operatorname{protein}(\mathrm{kg} / \mathrm{d}) .
\end{gathered}
$$

Feed ingredients and orts samples were dried in a $55^{\circ} \mathrm{C}$ forced-air oven for $72 \mathrm{~h}$ to determine DM content, ground in a Wiley mill (1-mm screen; Arthur H. Thomas Co., Philadelphia, PA), and analyzed for ash, NDF, $\mathrm{CP}$, and starch. All nutrients are expressed as percentages of DM, determined by drying at $105^{\circ} \mathrm{C}$ in a forcedair oven for more than $8 \mathrm{~h}$. Ash content was determined after $5 \mathrm{~h}$ of oxidation at $500^{\circ} \mathrm{C}$. Content of NDF was determined according to Mertens (2002). Crude protein was determined according to Hach et al. (1987). Starch was gelatinized with sodium hydroxide and hydrolyzed using an enzymatic method (Karkalas, 1985); glucose was then measured using a glucose oxidase method (PGO Enzyme Product No. P7119; Sigma-Aldrich, St. Louis, MO) and by determination of absorbance with a microplate reader (SpectraMax 190; Molecular Devices Corp., Sunnyvale, CA). Ether extract was determined according to AOAC International (2005; method 920.39). Starch digestibility of dried corn grain treatments was measured with a 7 -h in vitro fermentation with rumen microbes (Goering and VanSoest, 1970). Rumen fluid for the in vitro incubations was collected from a lactating cow on a high-starch diet. Each dried corn grain treatments was dry sieved through a sieve shaker (sieve apertures: 4,750, 2,360, 1,180, 600, 300, 150 , and $75 \mu \mathrm{m}$ bottom pan; model RX-86; W.S. Tyler Inc., Gastonia, NC) for approximately 20 min until the bottom pan weight was constant. Mean particle size of corn grain was calculated and wet sieved manually through the same set of sieves (ASAE, 1968). A composite of each feed ingredient was taken to determine $\mathrm{Cr}$ concentration of the diet. Samples were analyzed by 
electrothermal atomic absorption spectrophotometry according to Lloyd et al. (2010).

\section{Statistical Analysis}

Data were analyzed separately for the prepartum, $\mathrm{PP}$, and carryover periods. All daily and weekly data were analyzed using the MIXED procedure of SAS v.9.2 (SAS Institute Inc., Cary, NC) with repeated measures. The covariance structure used for analysis was first-order autoregressive because it resulted in the lowest Bayesian information criterion for most of the variables measured. Satterthwaite degrees of freedom adjustment was used to account for heterogeneous variances. Treatment effects on prepartum BW and BCS (measured every $2 \mathrm{wk}$ ) and daily DMI were analyzed with the following linear model:

$$
\begin{aligned}
\mathrm{Y}_{\mathrm{ijkmn}}= & \mu+\mathrm{B}_{\mathrm{i}}+\mathrm{C}\left(\mathrm{B}_{\mathrm{i}} \mathrm{K}_{\mathrm{k}}\right)_{\mathrm{j}}+\mathrm{K}_{\mathrm{k}}+\mathrm{T}_{\mathrm{m}} \\
& +\mathrm{K}_{\mathrm{k}} \mathrm{T}_{\mathrm{m}}+\mathrm{J}_{\mathrm{n}}+\mathrm{e}_{\mathrm{ijkmn}},
\end{aligned}
$$

where $\mu=$ overall mean, $B_{i}=$ random effect of block $(\mathrm{i}=1$ to 12$), \mathrm{C}\left(\mathrm{B}_{\mathrm{i}} \mathrm{K}_{\mathrm{k}}\right)_{\mathrm{j}}=$ random effect of cow $(\mathrm{j}=1$ to 4) within block and $\mathrm{Cr}$ treatment, $\mathrm{K}_{\mathrm{k}}=$ fixed effect of Cr treatment ( $\mathrm{k}=1$ to 2$), \mathrm{T}_{\mathrm{m}}=$ fixed effect of week $(\mathrm{BW}, \mathrm{BCS})$ or day $(\mathrm{DMI}), \mathrm{K}_{\mathrm{k}} \mathrm{T}_{\mathrm{m}}=$ interaction of $\mathrm{Cr}$ and day, $\mathrm{J}_{\mathrm{n}}=$ random effect of Julian date, and $\mathrm{e}_{\mathrm{ijkmn}}=$ residual. Cumulative DMI was analyzed with a similar model without the effect of time as a repeated measure. Treatment effects on daily DMI and milk yield, weekly milk components, FCM, ECM, and feed efficiency (FE; $3.5 \% \mathrm{FCM} / \mathrm{DMI}$ ), and BW and BCS measured every 2 or 4 wk during the PP and carryover periods were analyzed with a similar model, but with the addition of $\mathrm{S}_{1}=$ fixed effect of corn $(\mathrm{l}=1$ to 2$)$ and its interactions:

$$
\begin{aligned}
& Y_{i j k l m n}=\mu+B_{i}+C\left(B_{i} K_{k} S_{l}\right)_{j}+K_{k}+S_{1}+K_{k} S_{l} \\
& +T_{m}+K_{k} T_{m}+S_{l} T_{m}+K_{k} S_{l} T_{m}+J_{n}+e_{i j k l m n} .
\end{aligned}
$$

Treatment effects on cumulative DMI and cumulative milk yield during the PP and carryover periods were analyzed using the following linear model without repeated measures:

$$
\begin{aligned}
\mathrm{Y}_{\mathrm{ijkln}}=\mu & +\mathrm{B}_{\mathrm{i}}+\mathrm{C}\left(\mathrm{B}_{\mathrm{i}} \mathrm{K}_{\mathrm{k}} \mathrm{S}_{1}\right)_{\mathrm{j}}+\mathrm{K}_{\mathrm{k}}+\mathrm{S}_{1} \\
& +\mathrm{K}_{\mathrm{k}} \mathrm{S}_{1}+\mathrm{J}_{\mathrm{n}}+\mathrm{e}_{\mathrm{ijk} k \mathrm{n}} .
\end{aligned}
$$

Treatment differences within week were analyzed using the GLIMMIX procedure of SAS v.9.2 (SAS Institute Inc., Cary, NC) and the SLICE option. The model included the random effects of block, cow nested within block and treatment, and Julian date and the fixed effects of $\mathrm{Cr}$ and corn treatments and their interaction. The Bonferroni adjustment was applied to decrease the probability of type I error when multiple comparisons were done.

Normality of the residuals was checked with normal probability and box plots and homogeneity of variances with plots of residuals versus predicted values. Significance was determined at $P \leq 0.05$ for main effects and $P \leq 0.10$ for interactions. Tendencies were determined at $P \leq 0.10$ for main effects and $P \leq 0.15$ for interactions. All cows were in apparent good health at the beginning of the study. One of the cows receiving the $\mathrm{CrPr} / \mathrm{HMC}$ treatment combination was removed from the study due to an injury at $20 \mathrm{~d}$ PP; therefore, data for the last week on the treatment diet, cumulative DMI and milk yield for the treatment period, and all data for the carryover period were excluded from the statistical analyses. All other data were included.

\section{RESULTS}

\section{Prepartum Period}

All cows received the $\mathrm{CrPr}$ treatment for at least 15 d prepartum. Chromium propionate tended to decrease daily DMI prepartum (11.8 vs. $12.7 \mathrm{~kg} / \mathrm{d}, P=0.06)$, but did not affect cumulative DMI for the $14 \mathrm{~d}$ before parturition, BW, or BCS (Table 2).

\section{PP Period}

Chromium propionate and corn interacted over time to affect yield of $3.5 \% \mathrm{FCM}(P=0.07)$ and tended to interact to affect yields of ECM $(P=0.11)$ and lactose $(P=0.13$; Table 3$)$. The $\mathrm{CrPr} / \mathrm{HMC}$ treatment combination increased FCM during the last 2 wk of the PP period, whereas the Con/DC treatment decreased FCM during the first 2 wk PP compared with the other treatments (Figure 1). The $\mathrm{CrPr} / \mathrm{DC}$ and Con/HMC decreased FCM over time throughout the period. By the end of the treatment period, at $28 \mathrm{~d} \mathrm{PP}$, the $\mathrm{CrPr} /$ HMC treatment combination tended to increase FCM by $\sim 8.9 \mathrm{~kg} / \mathrm{d}$ compared with both Con/DC and Con/ HMC (57.4 vs. 48.6 and $48.5 \mathrm{~kg} / \mathrm{d}$, respectively, both $P$ $=0.10$ ). Similar effects of treatments were observed for yield ECM. High-moisture corn increased yields of milk (42.8 vs. $39.2 \mathrm{~kg} / \mathrm{d}, P=0.02)$ and lactose (2.11 vs. 1.94 $\mathrm{kg} / \mathrm{d}, P=0.05)$, as well as cumulative milk yield for the first $28 \mathrm{~d}$ PP (1,196 vs. $1,099 \mathrm{~kg}, P=0.02)$, compared with DC. Yields of fat and protein were not affected by treatment. High-moisture corn tended to decrease concentration of protein in milk (3.00 vs. $3.11 \%, P=$ $0.10)$ and tended to increase concentration of lactose in milk (4.69 vs. $4.60 \%, P=0.07$ ) compared with DC. Treatment did not affect concentrations of fat in milk. 
Daily DMI, cumulative DMI over 28 d PP, FE, and BCS were not affected by treatment. Overall, HMC tended to increase BW compared with DC throughout the period ( 728 vs. $695 \mathrm{~kg}, P=0.09$ ), and the difference in $\mathrm{BW}$ was greater at the beginning than at the end of the period (interaction $P=0.10$ ). The $\mathrm{Cr}$ treatment tended to increase BW compared with Con only at parturition (interaction $P=0.13$ ).

\section{Carryover Period}

Chromium propionate and corn treatments applied during the peripartum and PP period only, respectively, interacted with time to affect yields of FCM $(P$ $=0.07$ ) and tended to interact with time to affect daily milk yield $(P=0.11)$ when all cows were receiving a common diet during the carryover period ( 29 to $84 \mathrm{~d}$ PP; Table 4). Daily milk yield was consistently higher for $\mathrm{CrPr} / \mathrm{HMC}$ for most of the carryover period, consistently lower for Con/DC throughout the carryover period, and intermediate for $\mathrm{CrPr} / \mathrm{DC}$ and $\mathrm{Con} / \mathrm{HMC}$ (Figure 2a). However, treatments were no longer different for effects on milk yield by $56 \mathrm{~d}$ PP. Two weeks after treatments were terminated, FCM was $14.4 \mathrm{~kg} / \mathrm{d}$ greater for $\mathrm{CrPr} / \mathrm{HMC}$ than Con/DC $(P=0.001$; Figure 1) and $10.4 \mathrm{~kg} / \mathrm{d}$ greater for Con/HMC compared with Con/DC $(P=0.03)$. Interactions between treatments and time were detected for yield of ECM $(P \leq$ $0.05)$ with response patterns similar to that of FCM over time. Overall, $\mathrm{CrPr}$ tended to increase daily milk yield ( 55.4 vs. $52.0 \mathrm{~kg} / \mathrm{d}, P=0.09)$, ECM (51.7 vs. 48.3 $\mathrm{kg} / \mathrm{d}, P=0.09)$, and cumulative milk yield (3,142 vs. $2,952 \mathrm{~kg} / 56 \mathrm{~d}, P=0.10)$ compared with Con during the carryover period. Chromium propionate and corn treatments also interacted over time during the carryover period to affect daily DMI $(P=0.06)$; DMI was generally higher for $\mathrm{CrPr} / \mathrm{HMC}$, lower for Con/DC, and intermediate for $\mathrm{CrPr} / \mathrm{DC}$ and Con/HMC (Figure
$2 b)$. Overall, HMC tended to increase daily DMI (25.5 vs. $24.4 \mathrm{~kg} / \mathrm{d}, P=0.09)$ and cumulative DMI (1,445 vs. $1,386 \mathrm{~kg} / \mathrm{d}, P=0.09)$ compared with DC during the carryover period.

A sharp decrease in daily DMI and milk yield was observed for the $\mathrm{CrPr} / \mathrm{HMC}$ treatment combination at $\sim 60$ DIM (Figures 2a and 2b). Response curves to $\mathrm{CrPr} / \mathrm{HMC}$ were explained by a sharp decrease in daily DMI and milk yield observed at $62 \mathrm{~d}$ PP for 1 cow, combined with the expected stabilization or decline in milk yield that likely occurred as time progressed for all cows. Recovery in DMI took $\sim 10$ d to occur but milk yield was substantially lower for that cow for the remainder of the experiment, decreasing milk yield average for the whole group. Because we were unable to discern the reason for the loss of production, all data for that cow was included in the statistical analysis.

Even though no interactions between treatments were observed for milk fat concentration, $\mathrm{CrPr}$ and corn treatments interacted over time to affect milk fat yield $(P=0.09)$; $\mathrm{CrPr} / \mathrm{HMC}$ increased fat yield for the first 4 wk of the period, Con/DC decreased fat yield throughout the carryover period, and the other treatments were intermediate. Concentration of milk fat decreased following termination of the treatment period, but the decrease was faster for DC compared with HMC (interaction $P=0.01$ ). Overall, the $\mathrm{CrPr}$ treatment did not affect milk fat concentration during the carryover period. Chromium propionate and corn treatments interacted with time to affect milk protein concentration $(P=0.09)$; Con/DC and $\mathrm{CrPr} / \mathrm{HMC}$ consistently increased and decreased milk protein concentration, respectively, and the remaining treatments were generally intermediate. Overall, HMC decreased milk protein concentration compared with DC (2.77 vs. $2.85 \%, P=0.05)$. An interaction between $\mathrm{CrPr}$ and corn treatments with time was detected for milk protein yield $(P=0.01)$; milk protein yield increased during

Table 2. Effects of chromium propionate supplementation on DMI, BW, and BCS during the prepartum period ( $28 \mathrm{~d}$ before expected parturition date until parturition)

\begin{tabular}{|c|c|c|c|c|c|}
\hline \multirow[b]{2}{*}{ Item } & \multicolumn{2}{|c|}{ Treatment $^{1}$} & \multirow[b]{2}{*}{$\mathrm{SE}$} & \multicolumn{2}{|c|}{$P$-value } \\
\hline & Con & $\mathrm{CrPr}$ & & $\mathrm{CrPr}$ & $\mathrm{CrPr} \times$ time \\
\hline $\begin{array}{l}\mathrm{DMI},{ }^{2} \mathrm{~kg} / \mathrm{d} \\
\text { Cumulative } \mathrm{DMI},{ }^{3} \mathrm{~kg} \\
\mathrm{BW}^{5}{ }^{5} \mathrm{~kg} \\
\mathrm{BCS}^{5}\end{array}$ & $\begin{array}{l}12.7 \\
174 \\
764 \\
3.34\end{array}$ & $\begin{array}{c}11.8 \\
163 \\
797 \\
3.44\end{array}$ & $\begin{array}{c}0.42 \\
5.62 \\
21.2 \\
0.15\end{array}$ & $\begin{array}{l}0.06 \\
0.18 \\
0.16 \\
0.35\end{array}$ & $\begin{array}{l}0.95 \\
\mathrm{NA}^{4} \\
0.69 \\
0.49\end{array}$ \\
\hline
\end{tabular}

${ }^{1}$ Treatments were Con (control, ground corn) or CrPr (chromium propionate, KemTRACE Chromium Propionate, Kemin Industries, Des Moines, IA; $8 \mathrm{mg}$ of $\mathrm{Cr} /$ cow per day) top-dressed daily (20 g/d).

${ }^{2}$ Recorded daily.

${ }^{3}$ Calculated from -14 to $-1 \mathrm{~d}$ PP.

${ }^{4} \mathrm{NA}=$ not applicable.

${ }^{5}$ Recorded every 2 wk. 
Table 3. Effects of chromium propionate and corn grain source treatments ${ }^{1}$ on production responses of dairy cows during the treatment period (1 to $28 \mathrm{~d}$ postpartum)

\begin{tabular}{|c|c|c|c|c|c|c|c|c|c|c|c|}
\hline \multirow[b]{2}{*}{ Item $^{2}$} & \multicolumn{2}{|c|}{ Con } & \multicolumn{2}{|c|}{$\mathrm{CrPr}$} & \multirow[b]{2}{*}{$\mathrm{SE}$} & \multicolumn{6}{|c|}{$P$-value } \\
\hline & $\mathrm{DC}$ & $\mathrm{HMC}$ & $\mathrm{DC}$ & $\mathrm{HMC}$ & & $\mathrm{CrPr}$ & Corn & $\mathrm{Cr} \times$ corn & $\mathrm{CrPr} \times$ time & Corn $\times$ time & $\mathrm{CrPr} \times$ corn $\times$ time \\
\hline \multicolumn{12}{|l|}{ Yield, $\mathrm{kg} / \mathrm{d}$} \\
\hline Milk & 38.5 & 41.4 & 39.9 & 44.1 & 1.65 & 0.15 & 0.02 & 0.66 & 0.31 & 0.95 & 0.44 \\
\hline $3.5 \% \mathrm{FCM}$ & 49.3 & 51.1 & 50.8 & 54.9 & 2.80 & 0.25 & 0.20 & 0.60 & 0.19 & 0.86 & 0.07 \\
\hline ECM & 47.9 & 49.5 & 48.9 & 52.9 & 2.61 & 0.30 & 0.18 & 0.58 & 0.11 & 0.73 & 0.11 \\
\hline Fat & 1.95 & 1.99 & 2.00 & 2.17 & 0.13 & 0.28 & 0.33 & 0.53 & 0.30 & 0.82 & 0.16 \\
\hline Protein & 1.27 & 1.32 & 1.28 & 1.36 & 0.06 & 0.63 & 0.28 & 0.72 & 0.18 & 0.75 & 0.19 \\
\hline Lactose & 1.92 & 2.06 & 1.95 & 2.15 & 0.10 & 0.50 & 0.05 & 0.72 & 0.12 & 0.79 & 0.13 \\
\hline Cumulative milk, $\mathrm{kg}$ & 1,079 & 1,158 & 1,118 & 1,233 & 47.3 & 0.16 & 0.02 & 0.64 & $\mathrm{NA}^{3}$ & NA & NA \\
\hline \multicolumn{12}{|c|}{$\begin{array}{l}\text { Milk composition, } \% \\
\text { (unless otherwise noted) }\end{array}$} \\
\hline Fat & 4.83 & 4.59 & 4.77 & 4.80 & 0.21 & 0.70 & 0.62 & 0.51 & 0.47 & 0.90 & 0.36 \\
\hline Protein & 3.15 & 3.01 & 3.06 & 2.98 & 0.07 & 0.42 & 0.10 & 0.66 & 0.18 & 1.00 & 0.77 \\
\hline Lactose & 4.64 & 4.70 & 4.57 & 4.68 & 0.05 & 0.33 & 0.07 & 0.55 & 0.88 & 0.94 & 0.28 \\
\hline MUN, mg/dL & 14.0 & 14.4 & 14.1 & 14.1 & 0.66 & 0.93 & 0.71 & 0.73 & 0.40 & 0.86 & 0.02 \\
\hline $\mathrm{SCC}^{4} \times 1,000 / \mathrm{mL}$ & 21.3 & 32.0 & 24.9 & 25.3 & - & 0.90 & 0.54 & 0.55 & 0.06 & 0.66 & 0.06 \\
\hline DMI, $\mathrm{kg} / \mathrm{d}$ & 18.1 & 18.6 & 18.5 & 18.8 & 0.67 & 0.63 & 0.53 & 0.81 & 0.24 & 0.40 & 0.74 \\
\hline Cumulative DMI, kg & 507 & 521 & 519 & 527 & 19.7 & 0.60 & 0.51 & 0.83 & NA & NA & NA \\
\hline Feed efficiency ${ }^{5}$ & 2.68 & 2.70 & 2.59 & 2.83 & 0.14 & 0.81 & 0.34 & 0.42 & 0.31 & 0.40 & 0.60 \\
\hline $\mathrm{BW}, \mathrm{kg}$ & 692 & 708 & 698 & 748 & 21.8 & 0.25 & 0.09 & 0.37 & 0.13 & 0.10 & 0.18 \\
\hline BCS & 2.82 & 2.70 & 2.78 & 2.90 & 0.18 & 0.56 & 0.99 & 0.30 & 0.82 & 0.40 & 0.17 \\
\hline
\end{tabular}

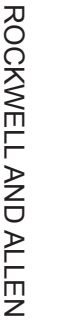

${ }^{1}$ Treatments were Con (control, ground corn) or CrPr (chromium propionate, KemTRACE Chromium Propionate, Kemin Industries, Des Moines, IA; 8 mg of Cr/cow per day) top-dressed daily $(20 \mathrm{~g} / \mathrm{d})$, and DC (dry corn) or HMC (high-moisture corn) in the base diet.

${ }^{2}$ All data were recorded weekly except for DMI and milk yield, which were recorded daily, and BW and BCS, which were recorded every 2 wk.

${ }^{3} \mathrm{NA}=$ not applicable.

${ }^{4}$ Data were log-transformed for analysis and least squares means were back-transformed for interpretation purposes.

${ }^{5} 3.5 \% \mathrm{FCM}(\mathrm{kg} / \mathrm{d}) / \mathrm{DMI}(\mathrm{kg} / \mathrm{d})$ 
the first $2 \mathrm{wk}$ of the carryover period for all treatments, and $\mathrm{CrPr} / \mathrm{HMC}$ increased milk protein yield compared with Con/DC during the first half of the period only. High-moisture corn increased milk lactose concentration compared with DC (4.83 vs. $4.71 \%, P=0.02)$ and $\mathrm{CrPr}$ tended to decrease lactose concentration compared with Con ( 4.72 vs. $4.81 \%, P=0.06)$. The treatment combination Con/HMC increased milk lactose yield at 6 wk PP compared with the other treatments, but decreased it thereafter and was similar to $\mathrm{CrPr} /$ $\mathrm{DC}$ at 10 wk PP (interaction $P=0.06$ ). In addition, $\mathrm{CrPr} / \mathrm{DC}$ decreased milk lactose yield compared with $\mathrm{Con} / \mathrm{DC}$ and $\mathrm{CrPr} / \mathrm{HMC}$ during the entire carryover period. Overall, HMC increased MUN compared with DC (16.4 vs. $15.3 \mathrm{mg} / \mathrm{dL}, P=0.03)$. Treatment effects on yields of milk components were no longer different by $56 \mathrm{~d} \mathrm{PP}$.

Body weight was consistently greater for $\mathrm{CrPr} / \mathrm{HMC}$ compared with the other treatments, but an interaction was detected between $\mathrm{CrPr}$ and corn treatments and time related to the variation among treatments over time $(P=0.05)$. High-moisture corn tended to decrease BCS over time compared with DC (interaction $P=$ 0.12 ), and no main effects of treatment were detected during the carryover period for BCS. Feed efficiency decreased for all treatments throughout the carryover period. An interaction between corn treatment and time indicated that $\mathrm{DC}$ decreased $\mathrm{FE}$ at a greater rate during the first $2 \mathrm{wk}$ of the carryover period compared with $\operatorname{HMC}(P=0.01)$.

\section{DISCUSSION}

Supplementation of Cr through the peripartum period has had inconsistent effects on milk yield. Although milk yield response has exceeded $3 \mathrm{~kg} / \mathrm{d}$ for certain treatments in several experiments (Hayirli et al., 2001; Terramoccia et al., 2005; Smith et al., 2005; Sadri et al., 2009; Soltan, 2010), others have reported no response during treatment of multiparous cows (Yang et al., 1996; Yasui et al., 2014). Smith et al. (2005) reported linear increases in DMI and yields of milk and FCM with $\mathrm{Cr}$ doses up to $\sim 7.5 \mathrm{mg} / \mathrm{d}$, but Hayirli et al. (2001) reported quadratic effects with the highest dose of $\sim 15.1 \mathrm{mg} / \mathrm{d}$ decreasing milk yield. Besides the amount supplemented, variation in response might have been caused by differences in diet composition.

Consistent with our hypothesis, CrPr interacted with corn source over time to affect yields of FCM during the treatment period. Similar interactions (or tendencies) were detected for yields of lactose and ECM, but not milk yield. Supplementation of $\mathrm{CrPr}$ increased FCM yield more over time with HMC compared with $\mathrm{DC}$, and this effect continued for several weeks after

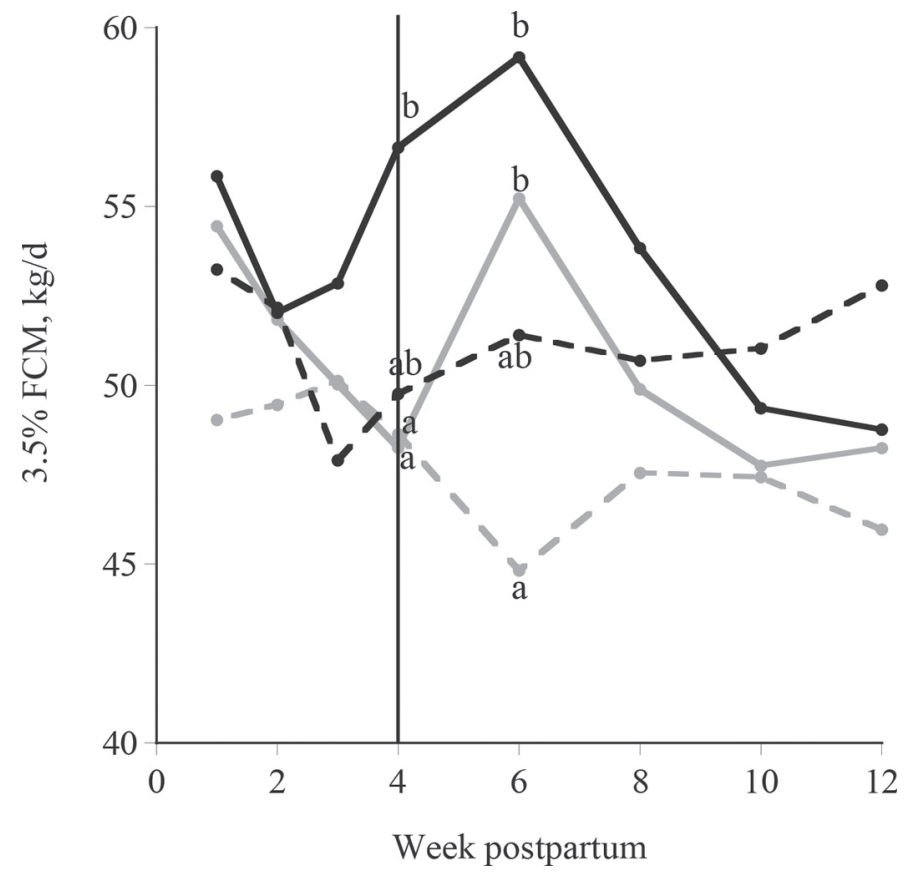

Figure 1. Effects of chromium propionate $(\mathrm{CrPr})$ and corn grain source varying in ruminal fermentability treatments on $3.5 \%$ FCM yield $(\mathrm{kg} / \mathrm{d})$ over time during the treatment ( 1 to $28 \mathrm{~d}$ postpartum) and carryover (29 to $84 \mathrm{~d}$ postpartum) periods. Treatments were control (Con; ground corn) or $\mathrm{CrPr}$ (KemTRACE Chromium Propionate, Kemin Industries, Des Moines, IA; $8 \mathrm{mg}$ of $\mathrm{Cr} /$ cow per day) topdressed daily $(20 \mathrm{~g} / \mathrm{d})$, and dry corn (DC) or high-moisture corn (HMC) in the base diet. Treatment combinations were Con/DC (gray, broken line); Con/HMC (gray, solid line); $\mathrm{CrPr} / \mathrm{DC}$ (black, broken line); and $\mathrm{CrPr} / \mathrm{HMC}$ (black, solid line). Weekly averages for treatment combinations were calculated with the data of 12 cows per treatment combination during both the treatment and carryover periods (n $=11$ for $\mathrm{CrPr} / \mathrm{HMC}$ during the carryover period). The line at $4 \mathrm{wk}$ indicates the start of the carryover period, when all cows were fed a common diet with no supplemental CrPr. Different letters (a,b) within week postpartum signify differences among treatments $(P<0.10$ at wk 4 and $P<0.05$ at wk 6$)$.

treatment ceased. Although carryover effects of treatment have not been generally measured in studies supplementing $\mathrm{Cr}$ in the peripartum period, a carryover effect has been reported previously; $\mathrm{CrPr}$ did not affect DMI or milk yield when supplemented from parturition until $35 \mathrm{~d}$ PP, but increased DMI and tended to increase milk yield after treatment ceased (McNamara and Valdez, 2005). Despite blocking, differences during the PP period are sometimes difficult to detect because of the large variability among cows during this period and because no suitable covariates exist to apply to the statistical models when treatments start immediately after parturition.

We expected the $\mathrm{CrPr}$ treatment to attenuate the expected depression in DMI by the HMC treatment during the PP period, but no effect of corn treatment or interactions with $\mathrm{CrPr}$ were detected for either daily or cumulative DMI during the PP period. However, $\mathrm{CrPr}$ 
Table 4. Effects of chromium propionate and corn grain source treatments ${ }^{1}$ on production responses of dairy cows when fed a common diet during the carryover period (29 to 84 d postpartum)

\begin{tabular}{|c|c|c|c|c|c|c|c|c|c|c|c|}
\hline \multirow[b]{2}{*}{ Item $^{2}$} & \multicolumn{2}{|c|}{ Con } & \multicolumn{2}{|c|}{$\mathrm{CrPr}$} & \multirow[b]{2}{*}{ SE } & \multicolumn{6}{|c|}{$P$-value } \\
\hline & $\mathrm{DC}$ & HMC & DC & HMC & & $\mathrm{CrPr}$ & Corn & $\mathrm{CrPr} \times$ corn & $\mathrm{CrPr} \times$ time & Corn $\times$ time & $\mathrm{CrPr} \times$ corn $\times$ time \\
\hline \multicolumn{12}{|l|}{ Yield, $\mathrm{kg} / \mathrm{d}$} \\
\hline Milk & 50.7 & 53.2 & 54.0 & 56.8 & 2.20 & 0.09 & 0.18 & 0.93 & 0.95 & 0.38 & 0.11 \\
\hline $3.5 \% \mathrm{FCM}$ & 46.9 & 49.9 & 51.1 & 53.7 & 2.30 & 0.11 & 0.20 & 0.91 & 0.81 & $<0.001$ & 0.07 \\
\hline ECM & 47.0 & 49.5 & 50.9 & 52.5 & 2.15 & 0.09 & 0.32 & 0.82 & 0.46 & $<0.001$ & 0.04 \\
\hline Fat & 1.56 & 1.70 & 1.72 & 1.83 & 0.10 & 0.11 & 0.18 & 0.87 & 0.79 & $<0.001$ & 0.09 \\
\hline Protein & 1.44 & 1.45 & 1.51 & 1.53 & 0.06 & 0.15 & 0.80 & 0.94 & 0.70 & 0.02 & 0.01 \\
\hline Lactose & 2.40 & 2.55 & 2.52 & 2.68 & 0.11 & 0.22 & 0.14 & 0.95 & 0.88 & 0.12 & 0.06 \\
\hline $\begin{array}{l}\text { Cumulative milk, } \mathrm{kg} \\
\text { Milk composition, } \%\end{array}$ & 2,882 & 3,022 & 3,061 & 3,222 & 127 & 0.10 & 0.18 & 0.92 & $\mathrm{NA}^{3}$ & NA & NA \\
\hline $\begin{array}{l}\text { (unless otherwise noted) } \\
\text { Fat }\end{array}$ & 3.14 & 3.27 & 3.22 & 3.28 & 0.14 & 0.74 & 0.42 & 0.78 & 0.96 & 0.01 & 0.34 \\
\hline Protein & 2.88 & 2.78 & 2.81 & 2.75 & 0.04 & 0.19 & 0.05 & 0.70 & 0.56 & 0.87 & 0.09 \\
\hline Lactose & 4.76 & 4.86 & 4.65 & 4.79 & 0.05 & 0.06 & 0.02 & 0.68 & 0.34 & 0.44 & 0.78 \\
\hline MUN, mg/dL & 15.2 & 16.1 & 15.3 & 16.7 & 0.54 & 0.54 & 0.03 & 0.66 & 0.97 & 0.20 & 0.92 \\
\hline $\mathrm{SCC},{ }^{4} \times 1,000 / \mathrm{mL}$ & 12.6 & 16.2 & 12.3 & 16.0 & - & 0.97 & 0.56 & 0.99 & 0.35 & 0.37 & 0.01 \\
\hline DMI, kg/d & 24.1 & 25.2 & 24.7 & 25.7 & 0.62 & 0.33 & 0.09 & 0.85 & 0.76 & 0.02 & 0.06 \\
\hline Cumulative DMI, kg & 1,366 & 1,430 & 1,406 & 1,459 & 35.0 & 0.31 & 0.09 & 0.87 & NA & NA & NA \\
\hline Feed efficiency ${ }^{5}$ & 2.01 & 2.03 & 2.11 & 2.20 & 0.09 & 0.11 & 0.53 & 0.69 & 0.66 & 0.01 & 0.21 \\
\hline BW, kg & 642 & 648 & 650 & 681 & 18.1 & 0.20 & 0.27 & 0.41 & 0.15 & 0.40 & 0.05 \\
\hline BCS & 2.23 & 2.05 & 2.30 & 2.19 & 0.18 & 0.42 & 0.31 & 0.88 & 0.96 & 0.12 & 0.75 \\
\hline
\end{tabular}

${ }^{1}$ Treatments were Con (control, ground corn) or CrPr (chromium propionate, KemTRACE ${ }^{\circledR}$ Chromium Propionate, Kemin Industries, Des Moines, IA; 8 mg of Cr/cow per day) top-dressed daily $(20 \mathrm{~g} / \mathrm{d})$, and DC (dry corn) or HMC (high-moisture corn) in the base diet.

${ }^{2}$ All data were recorded every 2 weeks except for DMI and milk yield, which were recorded daily, and BW and BCS, which were recorded every 4 wk.

${ }^{3} \mathrm{NA}=$ not applicable.

${ }^{4}$ Data were log-transformed for analysis and least squares means were back-transformed for interpretation purposes.

${ }^{5} 3.5 \% \mathrm{FCM}(\mathrm{kg} / \mathrm{d}) / \mathrm{DMI}(\mathrm{kg} / \mathrm{d})$. 
a)

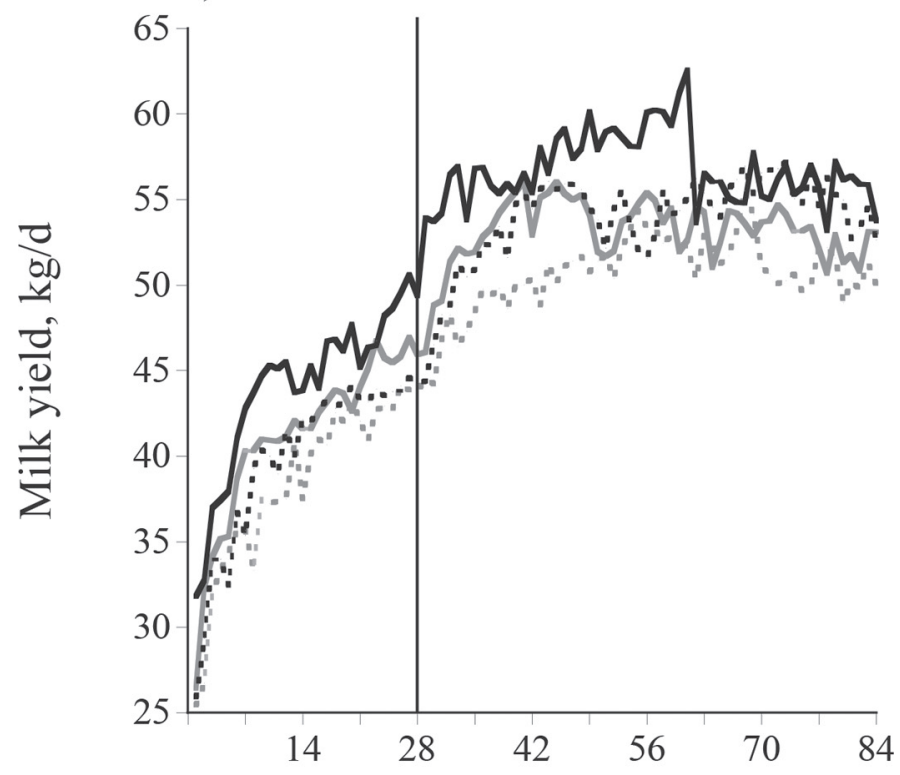

b)

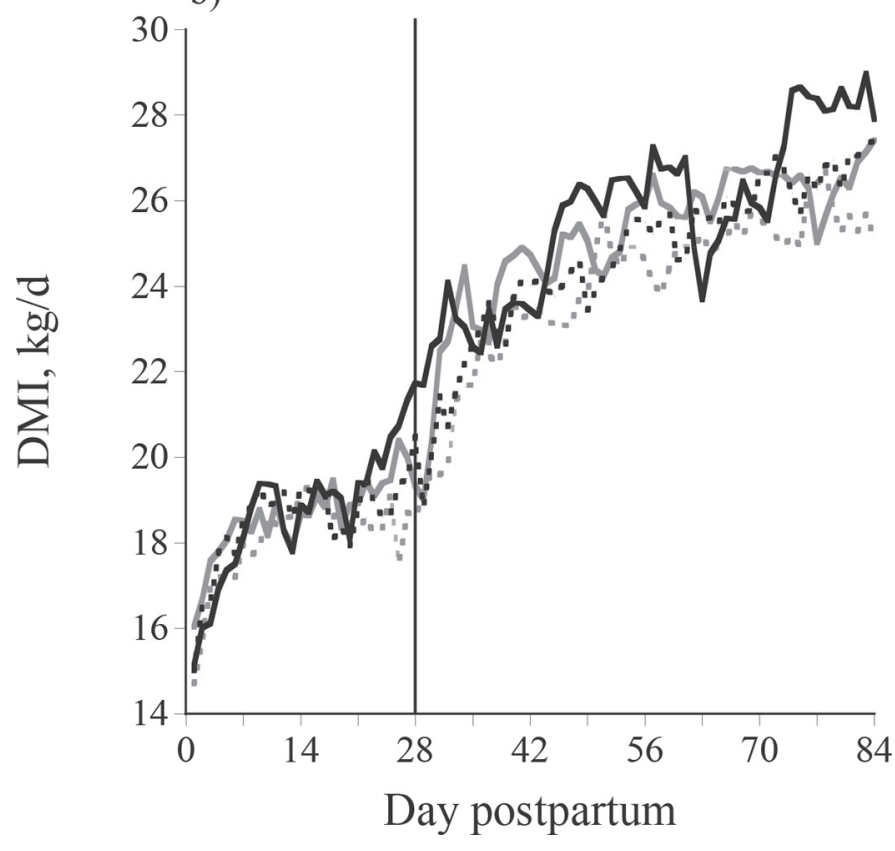

Figure 2. Effects of chromium propionate $(\mathrm{CrPr})$ and corn grain source varying in ruminal fermentability treatments on (a) milk yield $(\mathrm{kg} / \mathrm{d})$ and $(\mathrm{b})$ DMI $(\mathrm{kg} / \mathrm{d})$ over time during the treatment (1 to $28 \mathrm{~d}$ postpartum) and carryover (29 to $84 \mathrm{~d}$ postpartum) periods. Treatments were control (Con; ground corn) or CrPr (KemTRACE Chromium Propionate, Kemin Industries, Des Moines, IA; $8 \mathrm{mg}$ of $\mathrm{Cr} /$ cow per day) top-dressed daily $(20 \mathrm{~g} / \mathrm{d}$ ), and dry corn (DC) or highmoisture corn (HMC) in the base diet. Treatment combinations were Con/DC (gray, broken line); Con/HMC (gray, solid line); $\mathrm{CrPr} / \mathrm{DC}$ (black, broken line); and CrPr/HMC (black, solid line). Daily averages for treatment combinations were calculated with the data of 12 cows per treatment combination during both the treatment and carryover periods ( $\mathrm{n}=11$ for $\mathrm{CrPr} / \mathrm{HMC}$ during the carryover period). The line at d 28 indicates the start of the carryover period, when all cows were fed a common diet with no supplemental CrPr. interacted with corn source over time to affect DMI during the carryover period after treatment ceased and cows were offered a common diet with treatment effects similar to those for FCM. Although the effects of $\mathrm{Cr}$ on DMI and milk yield over time in a previous experiment suggests that the increase in DMI preceded the increase in milk yield (Smith et al., 2005), consistent with our expectations, it appears that treatment effects on milk yield preceded their effects on DMI in our experiment.

The HMC was more fermentable in vitro than the DC, and we expected it to increase propionic acid production and depress DMI compared with DC during the treatment period when cows were in a lipolytic state, which did not occur. Propionic acid has been shown to be hypophagic in many experiments, possibly through stimulation of hepatic oxidation (Allen, 2000), and continuous infusion of propionate was more hypophagic when infused in cows in the PP period compared with mid lactation (Oba and Allen, 2003). This is likely because cows in the PP period are in a lipolytic state with elevated plasma fatty acid concentration and hepatic acetyl CoA content (Allen et al., 2009); greater hypophagic effects of propionate for cows in a lipolytic state might be because propionate stimulates oxidation of the pool of acetyl CoA in the liver (Allen, 2014). In support of this, hypophagia from propionate infusion was linearly related to liver acetyl CoA concentration in experiments from our laboratory (Stocks and Allen, 2012, 2013).

Several experiments have fed diets differing in starch content in the PP period (Andersen et al., 2003; Rabelo et al., 2005; Dann and Nelson, 2011). Increasing diet starch content increased DMI and milk yield in experiments reported by Andersen et al. (2003) and Rabelo et al. (2005), but in those experiments grains were substituted for forage, increasing the forage NDF content of the diet. Forage NDF is very filling (Allen, 2000) and large increases in the forage NDF content of diets in these studies likely contributed to satiety by increasing ruminal distention, especially as lactation progressed and the lipolytic state diminished. Dann and Nelson (2011) substituted corn meal for nonforage fiber sources to increase diet starch content from 21.0 to $25.5 \%$, and the higher-starch diet decreased DMI by $1.5 \mathrm{~kg} / \mathrm{d}$. Nonforage fiber sources are much less filling than forage NDF (Allen, 2000), so the filling effects of the treatment diets were likely more similar in that experiment than in experiments where grains are substituted for forage. To our knowledge, only 2 previous experiments have evaluated the effects of ruminal fermentability of starch in diets fed to cows in the PP period (Dann et al., 1999; Sadri et al., 2009). Increasing ruminal starch fermentability by substituting steam-flaked corn for cracked corn tended to decrease DMI by more than 
$1 \mathrm{~kg} / \mathrm{d}$ over the first $63 \mathrm{~d}$ PP (Dann et al., 1999), although interactions with time were not reported and greater ruminal fermentability would be expected to have a greater effect in the first few weeks of lactation. Treatment effects on DMI for the experiment reported by Sadri et al. (2009) are discussed below.

Chromium supplementation increases insulin sensitivity in nonlactating growing heifers (Sumner et al., 2007), and we hypothesized that $\mathrm{Cr}$ would increase DMI through the peripartum period by increasing insulin sensitivity and decreasing lipolysis. Decreased lipolysis might decrease hypophagia in the PP period by reducing the supply of fatty acids to the liver according to the hepatic oxidation theory of control of feed intake (Allen et al., 2009). Chromium supplementation increased both prepartum and PP DMI in dairy cows in an experiment reported by Hayirli et al. (2001), but effects of Cr supplementation on DMI through the PP period have been inconsistent. Supplementation of $\mathrm{Cr}$ did not affect DMI in other experiments in either the prepartum period (Yang et al., 1996; McNamara and Valdez, 2005; Smith et al., 2005; Sadri et al., 2009) or the PP period (McNamara and Valdez, 2005; Smith et al., 2005; Sadri et al., 2009; Soltan, 2010; Yasui et al., 2014). The reduction in daily DMI during the prepartum period by $\mathrm{CrPr}$ supplementation in our experiment is unique among studies, although no effect of treatment on cumulative DMI was noted over the $14 \mathrm{~d}$ prepartum.

Just one other experiment, to our knowledge, evaluated effects of starch source and Cr supplementation (Sadri et al., 2009). In that experiment, starch source interacted with $\mathrm{Cr}$ supplementation to affect DMI when both treatments were fed through the peripartum period from $21 \mathrm{~d}$ before expected parturition until $28 \mathrm{~d}$ PP. The more fermentable barley treatment decreased DMI compared with corn for the control treatment during both the prepartum and $\mathrm{PP}$ periods and $\mathrm{Cr}$ increased DMI for the barley treatment only (Sadri et al., 2009). The effects of $\mathrm{Cr}$ on milk yield paralleled its effect on DMI, increasing yields of milk and milk solids for the barley treatment only (interactions $P=$ 0.16 and 0.10 , respectively). These results, unlike ours, are consistent with our expectations according to the hepatic oxidation theory of the control of feed intake (Allen et al., 2009).

Increased insulin sensitivity is expected to reduce net lipolysis, decreasing loss of body condition and BW as well as milk fat by decreasing plasma fatty acid concentration. However, $\mathrm{CrPr}$ did not increase BW or BCS either prepartum or PP in our experiment, which is consistent with other studies for effects of Cr supplementation on BW (Yang et al., 1996; McNamara and Valdez, 2005; Smith et al., 2005; Soltan, 2010; Yasui et al., 2014) and BCS (Yang et al., 1996; McNamara and Valdez, 2005; Yasui et al., 2014). Whereas Smith et al. (2005) reported that $\mathrm{Cr}$ increased BCS linearly during the prepartum period, they concluded there was little biological significance in the values, as the change was very small and no effects on BCS during the PP period were observed. In addition, $\mathrm{CrPr}$ treatment did not affect milk fat concentration or yield during the PP period in our experiment, consistent with other studies (Yang et al., 1996; Hayirli et al., 2001; Kafilzadeh et al., 2012; Smith et al., 2005; Yasui et al., 2014).

\section{CONCLUSIONS}

Our study shows that the effects of $\mathrm{CrPr}$ on production responses are dependent upon the fermentability of starch in the diets fed during the PP period. This might explain some of the differences observed among studies that have supplemented $\mathrm{Cr}$ through the peripartum period that have been reported in the literature. Diets fed during the PP period that contain highly fermentable starch might benefit more from Cr supplementation. Production responses to $\mathrm{CrPr}$ and corn source continued for several weeks after treatment ceased, suggesting a programming effect of treatment during the peripartum period, which should be investigated further. Because of its putative effects on insulin sensitivity, we expected $\mathrm{CrPr}$ to increase feed intake before increasing milk yield, but the opposite occurred. Lack of effects of $\mathrm{Cr}$ on BW, BCS, and milk fat in this and other studies, in addition to the effects of $\mathrm{Cr}$ on milk yield preceding its effects on DMI in this study, suggests that the stimulation of milk yield by $\mathrm{Cr}$ supplementation might not be through its effect on feed intake and might involve mechanisms other than, or in addition to, its putative effects on insulin sensitivity.

\section{ACKNOWLEDGMENTS}

We thank Kemin Agrifoods North America Inc. (Des Moines, IA) for funding in support of this experiment. We thank R. A. Longuski and D. G. Main (Allen Laboratory, Michigan State University) for technical assistance, Paola Piantoni for editing the manuscript, Jerry W. Spears (Department of Animal Science, North Carolina State University) for analysis of chromium in feeds, and the staff and students at the Michigan State University Dairy Teaching and Research Center for animals care.

\section{REFERENCES}

Allen, M. S. 2000. Effects of diet on short-term regulation of feed intake by lactation dairy cattle. J. Dairy Sci. 83:1598-1624.

Allen, M. S. 2014. Drives and limits to feed intake in ruminants. Anim. Prod. Sci. 54:1513-1524. 
Allen, M. S., B. J. Bradford, and K. J. Harvatine. 2005. The cow as a model to study food intake regulation. Annu. Rev. Nutr. 25:523547.

Allen, M. S., B. J. Bradford, and M. Oba. 2009. Board invited review: The hepatic oxidation theory of the control of feed intake and its application to ruminants. J. Anim. Sci. 87:3317-3334.

Allen, M. S., and P. Piantoni. 2013. Metabolic control of feed intake: implications for metabolic disease of fresh cows. Vet. Clin. North Am. Food Anim. Pract. 29:279-297.

Andersen, J. B., N. C. Friggens, K. Sejrsen, M. T. Sorensen, L. Munksgaard, and K. L. Ingvartsen. 2003. The effects of low vs. high concentrate level in the diet on performance in cows milked two or three times daily in early lactation. Livest. Prod. Sci. 81:119-128.

AOAC International. 1997. Official Methods of Analysis. 16th ed. AOAC Int., Gaithersburg, MD.

AOAC International. 2005. Official Methods of Analysis. 18th ed. AOAC Int., Gaithersburg, MD.

ASAE. 1968. Method of determining and expressing fineness of feed material by sieving. ASAE standard S319. St. Joseph, MI.

Bell, A. W. 1995. Regulation of organic nutrient metabolism during transition from late pregnancy to early lactation. J. Anim. Sci. $73: 2804-2819$.

Bradford, B. J., and M. S. Allen. 2007. Depression in feed intake by a highly fermentable diet is related to plasma insulin concentration and insulin response to glucose infusion. J. Dairy Sci. 90:38383845 .

Clodfelder, B. J., B. M. Gullick, H. C. Lukaski, Y. Neggers, and J. B. Vincent. 2005. Oral administration of biomimetic $\left[\mathrm{Cr}_{3} \mathrm{O}\left(\mathrm{O}_{2} \mathrm{CCH}_{2} \mathrm{CH}_{3}\right)_{6}\left(\mathrm{H}_{2} \mathrm{O}\right)_{3}\right]+$ increases insulin sensitivity and improves blood plasma variables in healthy and type 2 diabetic rats. J. Biol. Inorg. Chem. 10:119-130.

Dann, H. M., and B. H. Nelson. 2011. Early lactation diets for dairy cattle-Focus on starch. Pages 46-56 in Proc. Cornell Nutrition Conference for Feed Manufacturers. Department of Animal Science, Cornell University, Ithaca, NY.

Dann, H. M., G. A. Varga, and D. E. Putnam. 1999. Improving energy supply to late gestation and early postpartum dairy cows. J. Dairy Sci. 82:1765-1778

Forbes, J. M. 2007. Voluntary Food Intake and Diet Selection in Farm Animals. CAB International: Oxon, UK.

Goering, H. K., and P. J. Van Soest. 1970. Forage Fiber Analysis (Apparatus, Reagents, Procedures, and Some Applications). Agricultural Handbook no. 379. Agricultural Research Service-USDA, Washington, DC.

Hach, C. C., B. K. Bowden, A. B. Lopelove, and S. V. Brayton. 1987. More powerful peroxide Kjeldahl digestion method. J. Asocc. Off. Anal. Chem. 70:783-787.

Hayirli, A., D. R. Bremmer, S. J. Bremmer, S. J. Bertics, M. T. Socha, and R. R. Grummer. 2001. Effects of chromium supplementation on production and metabolic parameters in periparturient dairy cows. J. Dairy Sci. 84:1218-1230

Hobson, P. N. 1972. Physiological characteristics of rumen microbes and relation to diet and fermentation patterns. Proc. Nutr. Soc. 31:135-139.

Kafilzadeh, F., H. K. Shabankareh, and M. R. Targhibi. 2012. Effect of chromium supplementation on productive and reproductive performances and some metabolic parameters in late gestation and early lactation of dairy cows. Biol. Trace Elem. Res. 149:42-49.

Karkalas, J. 1985. An improved enzymatic method for the determination of native and modified starch. J. Sci. Food Agric. 36:10191027.

Lloyd, K. E., V. Fellner, S. J. McLeod, R. S. Fry, K. Krafka, A. Lamptey, and J. W. Spears. 2010. Effects of supplementing dairy cows with chromium propionate on milk and tissue chromium concentrations. J. Dairy Sci. 93:4774-4780.
Matthews, J. O., L. L. Southern, J. M. Fernandez, J. E. Pontif, T. D. Bidner, and R. L. Odgaard. 2001. Effects of chromium picolinate and chromium propionate on glucose and insulin kinetics of growing barrows and on growth and carcass traits of growing-finishing barrows. J. Anim. Sci. 79:2172-2178.

McNamara, J. P., and F. Valdez. 2005. Adipose tissue metabolism and production responses to calcium propionate and chromium propionate. J. Dairy Sci. 88:2498-2507.

Mertens, D. R. 2002. Gravimetric determination of amylase-treated neutral detergent fiber in feeds using refluxing in beakers or crucibles: collaborative study. J. AOAC Int. 85:1217-1240.

NRC. 2001. Nutrient Requirements of Dairy Cattle. 7th rev. ed. Natl. Acad. Sci., Washington, DC.

Oba, M., and M. S. Allen. 2003. Dose-response effects of intraruminal infusion of propionate on feeding behavior of lactating cows in early or midlactation. J. Dairy Sci. 86:2922-2931.

Rabelo, E., R. L. Rezende, S. J. Bertics, and R. R. Grummer. 2005. Effects of pre- and postfresh transition diets varying in dietary energy density on metabolic status of periparturient dairy cows. J. Dairy Sci. 88:4375-4383.

Sadri, H., G. R. Ghorbani, H. R. Rahmani, A. H. Samie, M. Khorvash, and R. M. Bruckmaier. 2009. Chromium supplementation and substitution of barley grain with corn: Effects on performance and lactation in periparturient dairy cows. J. Dairy Sci. 92:5411-5418.

Smith, K. L., M. R. Waldron, J. K. Drackley, M. T. Socha, and T. R. Overton. 2005. Performance of dairy cows as affected by prepartum dietary carbohydrate source and supplementation with chromium throughout the transition period. J. Dairy Sci. 88:255-263.

Soltan, M. A. 2010. Effect of dietary chromium supplementation on productive and reproductive performance of early lactating dairy cows under heat stress. J. Anim. Physiol. Anim. Nutr. (Berl.) 94:264-272.

Stocks, S. E., and M. S. Allen. 2012. Hypophagic effects of propionate increase with elevated hepatic acetyl CoA concentration of cows in the early postpartum period. J. Dairy Sci. 95:3259-3268.

Stocks, S. E., and M. S. Allen. 2013. Hypophagic effects of propionic acid are not attenuated during a 3-day infusion in the early postpartum period in Holstein cows. J. Dairy Sci. 96:4615-4623.

Subiyatno, A., D. N. Mowat, and W. Z. Yang. 1996. Metabolite and hormonal responses to glucose or propionate infusions in periparturient dairy cows supplemented with chromium. J. Dairy Sci. 79:1436-1445.

Sumner, J. M., F. Valdez, and J. P. McNamara. 2007. Effects of chromium propionate on response to an intravenous glucose tolerance test in growing Holstein heifers. J. Dairy Sci. 90:3467-3474.

Terramoccia, S., S. Bartocci, and E. Lillini. 2005. Milk yield and immune response of periparturient and early lactation Friesian cows fed diets supplemented with a high level of amino-acid chelated chromium. Asian-australas. J. Anim. Sci. 18:1098-1104.

Wang, Z. Q., and W. T. Cefalu. 2010. Current concepts about chromium supplementation in type 2 diabetes and insulin resistance. Curr. Diab. Rep. 10:145-151.

Wildman, E. E., G. M. Jones, P. E. Wagner, R. L. Boman, H. F. Troutt Jr., and T. N. Lesch. 1982. A dairy cow body condition scoring system and its relationship to selected production characteristics. J. Dairy Sci. 65:495-501.

Yang, W. Z., D. N. Mowat, A. Subiyatno, and R. M. Liptrap. 1996. Effects of chromium supplementation on early lactation performance of Holstein cows. Can. J. Anim. Sci. 76:221-230.

Yasui, T., J. A. A. McArt, C. M. Ryan, R. O. Gilbert, D. V. Nydam, F. Valdez, K. E. Griswold, and T. R. Overton. 2014. Effects of chromium propionate supplementation during the periparturient period and early lactation on metabolism, performance, and cytological endometritis in dairy cows. J. Dairy Sci. 97:6400-6410. 